University of Nebraska - Lincoln

DigitalCommons@University of Nebraska - Lincoln

1994

\title{
Engaging with Shakespeare: Responses of George Eliot and Other Women Novelists
}

Marianne Novy

University of Georgia

Follow this and additional works at: https://digitalcommons.unl.edu/ger

Part of the Comparative Literature Commons, Literature in English, British Isles Commons, and the Women's Studies Commons

Novy, Marianne, "Engaging with Shakespeare: Responses of George Eliot and Other Women Novelists" (1994). The George Eliot Review. 252.

https://digitalcommons.unl.edu/ger/252

This Article is brought to you for free and open access by the English, Department of at DigitalCommons@University of Nebraska - Lincoln. It has been accepted for inclusion in The George Eliot Review by an authorized administrator of DigitalCommons@University of Nebraska - Lincoln. 


\title{
Ruth Harris \\ Engaging with Shakespeare: Responses of George Eliot and Other Women Novelists by Marianne Novy (University of Georgia Press, 1994)
}

\begin{abstract}
Virginia Woolf's comment, 'Literature is no one's private ground; literature is common ground', is a reminder in this age of intertextuality that writers have always lived off one another. Shakespeare himself was no exception. Marianne Novy's interest begins, however, with response rather than replication, and especially with the reasons why women novelists are drawn to Shakespeare. Unlike Sandra Gilbert and Susan Gubar, the authors of The Madwoman in the Attic (1979), who portray male writers as essentially alienating to women, Novy shows how women who feel marginalized respond to Shakespeare the outsider, mourning his 'outcast state'; how women's need to 'perform', to be flexible and versatile, draws them to Shakespeare the actor; above all, how their innate compassion and tolerance guide them towards Shakespeare the 'artist of sympathy' and his wide-ranging identification with his characters. She finds his attractions particularly evident in the nineteenth century but increasingly challenged in the twentieth.
\end{abstract}

Although Marianne Novy deals interestingly with Jane Austen's preference for Shakespearean comedy and Charlotte Brontë's evocation of tragedy, it is with George Eliot, the 'female Shakespeare, so to speak', that she comes into her own. In youth when female friendships were important, George Eliot was drawn to Rosalind and Celia and the cross-dressing of heroines; when her defining relationship became her love for Lewes, she warmed to Shakspeare's creation of powerful and unconventional women, given to frank avowals of love; during the whole process of maturing, she valued Shakespeare as one who, like herself, enjoyed presenting 'mixed human beings in such a way as to call forth tolerance, judgement, pity and sympathy'. Her re-writing of Shakespeare is shown to extend that sympathy so that the mediocre have their tragedies too. Novy's tracing of Shakespearean echoes, parallels and contrasts is often perceptive and illuminating. A question arises in my mind, however, when she concedes that George Eliot need not have planned every Shakespearean allusion consciously. If so, how much is authorial response (which the title promises) and how much is critical speculation? For example, when Eliot refers to Rosamond Vincy's chain, is this a conscious response to the chain given by Rosalind to Orlando? Or when Felix Holt describes himself as 'a man... warned by visions', is she recalling Hamlet's vision of his father's ghost? Unconscious echoes are not, of course, without value since they can still add great richness to the text. There is a wealth of meaning in Knoepflmacher's comparison of Silas Marner with The Winter's Tale that is not dependent on authorial intention. As A. van den Broek indicates, ${ }^{1}$ epigraphs drawn from Shakespeare are helpful and certainly assist Novy when she links Felix with Coriolanus. Two major themes in Middlemarch, sympathy and marriage, are clearly shown to engage with Shakespeare's treatment of the same themes in his sonnets and comedies. In Daniel Deronda, described as 'the most consciously Shakespearean of all her novels', Novy reveals how George Eliot reads and reviews Shakespeare from a 
woman's point of view. Gwendolen is both like and unlike Rosalind; her acting of Hermione suggests that 'she often sees life in terms of theatre, but without understanding the demands of either'. In his wide-ranging sympathy Deronda is likened to Shakespeare, in his questioning irresolution to Hamlet, and in both to George Eliot herself. She is seen as more universal than Shakespeare, however, in her treatment of Judaism. Her sympathy crosses the bounds of race, class and gender with a passion that not even he, with all his claims to universality, can match.

Novy's comments on twentieth-century writers stimulate. After thoughtful discussion of Willa Cather, Virginia Woolf and Iris Murdoch, she deals with more explicit feminist protest from Margaret Drabble and Margaret Atwood. Finally in a chapter cumbrously called 'Shakespeare and the Cultural Hybridity of Contemporary Women Novelists', she shows how recent writers rebel against what they see as Shakespeare's limitations. Angela Carter breaks down the link between art and sympathy; Gloria Naylor and Nadine Gordimer cross racial boundaries; Jane Smiley's novel, A Thousand Acres, transforms the plot of King Lear by giving it a modern mid-west setting, fiercely criticizing patriarchal authority and re-telling the story from the eldest daughter's point of view.

This is a wide-ranging survey of women writers. Too wide-ranging? Some readers may think so, but its firm unity of theme and approach guard against diffuseness. Novy structures her arguments carefully, introducing each chapter with a summary of principal themes before she attempts more detailed exploration. She delights in close reading, marshalling of evidence and ample use of quotations to prove her points. A wealth of notes at the end may irritate the impatient reader who flips from page to note but the annotations are helpful and responsible. Her writing is clear, refreshingly free from academic tonguetwisters - with only occasional reference to 'valourisation', 'historicise' and 'heteroglossia' to impede its flow. Admittedly, her style lacks the sparkle and sting of The Madwoman in the Attic, but what she lacks in liveliness of phrase she makes up for in quiet balance and scrupulous attention to detail.

In a book full of women's voices responding to Shakespeare and re-writing him, perhaps the most exhilarating cry comes from Maya Angelou: 'Nobody else understands it, but I know that William Shakespeare was a black woman.' In the teeth of other protests, such a claim is surely cause for celebration.

Note

1. 'Shakespeare at the Heart of George Eliot's England', George Eliot - George Henry Lewes Studies, 24-5 (1993), 36-64. 